\title{
Effective Improvement of the Photovoltaic Performance of Carbon-Based Perovskite Solar Cells by Additional Solvents
}

\author{
Chenxi Zhang $^{1} \cdot$ Yudan $^{\text {Luo }}{ }^{1} \cdot$ Xiaohong Chen $^{1} \cdot$ Yiwei Chen $^{1} \cdot$ Zhuo Sun $^{1} \cdot$ Sumei Huang $^{1}$
}

Received: 22 March 2016/Accepted: 10 May 2016/Published online: 31 May 2016

(C) The Author(s) 2016. This article is published with open access at Springerlink.com

\begin{abstract}
A solvent-assisted methodology has been developed to synthesize $\mathrm{CH}_{3} \mathrm{NH}_{3} \mathrm{PbI}_{3}$ perovskite absorber layers. It involved the use of a mixed solvent of $\mathrm{CH}_{3} \mathrm{NH}_{3} \mathrm{I}, \mathrm{PbI}_{2}, \gamma$-butyrolactone, and dimethyl sulfoxide (DMSO) followed by the addition of chlorobenzene (CB). The method produced ultra-flat and dense perovskite capping layers atop mesoporous $\mathrm{TiO}_{2}$ films, enabling a remarkable improvement in the performance of free hole transport material (HTM) carbon electrode-based perovskite solar cells (PSCs). Toluene (TO) was also studied as an additional solvent for comparison. At the annealing temperature of $100{ }^{\circ} \mathrm{C}$, the fabricated HTM-free PSCs based on drop-casting CB demonstrated power conversion efficiency (PCE) of $9.73 \%$, which is 36 and $71 \%$ higher than those fabricated from the perovskite films using TO or without adding an extra solvent, respectively. The interaction between the $\mathrm{PbI}_{2}-\mathrm{DMSO}-\mathrm{CH}_{3} \mathrm{NH}_{3} \mathrm{I}$ intermediate phase and the additional solvent was discussed. Furthermore, the influence of the annealing temperature on the absorber film formation, morphology, and crystalline structure was investigated and correlated with the photovoltaic performance. Highly efficient, simple, and stable HTM-free solar cells with a PCE of $11.44 \%$ were prepared utilizing the optimum perovskite absorbers annealed at $120^{\circ} \mathrm{C}$.
\end{abstract}

Keywords Halide perovskite $\cdot$ Solar cell $\cdot$ Spin-coating $\cdot$ Carbon counter electrode $\cdot$ Free hole transporting material

\section{Introduction}

During the past 5 years, there has been a surging interest in the study of organic-inorganic hybrid perovskite compounds for applications in photovoltaic devices because of low cost, simple fabrication process, and high-efficiency solar power conversion [1-6]. Typically, perovskite solar cells (PSCs) employed a mesoporous titania or alumina scaffold, a methylammonium (MA) lead iodide perovskite light absorber, an organic hole transport material (HTM), characteristically spiro-OMeTAD $\left(2,2^{\prime}, 7,7^{\prime}\right.$-tetrakis- $(N, N$ -

Sumei Huang

smhuang@phy.ecnu.edu.cn

1 Engineering Research Center for Nanophotonics \& Advanced Instrument, Ministry of Education, Department of Physics, East China Normal University, Shanghai 200062, People's Republic of China di-p-methoxyphenylamine)-9, $9^{\prime}$-bifluorene), and an $\mathrm{Au}$ or Ag electrode. PSCs achieved a power conversion efficiency (PCE) of $>10 \%$ in 2012 [2,3]. $\mathrm{TiO}_{2} /$ spiro-OMeTAD is regarded as a successful couple owing to its good optical transparency and perfect band alignment with respect to $\mathrm{CH}_{3} \mathrm{NH}_{3} \mathrm{PbI}_{3}$. Later, the PCEs were improved to $15 \%$ using a two-step sequential deposition technique, involving spin-coating of a $\mathrm{PbI}_{2}$ followed by exposure to a solution of $\mathrm{CH}_{3} \mathrm{NH}_{3} \mathrm{I}$ to form $\mathrm{CH}_{3} \mathrm{NH}_{3} \mathrm{PbI}_{3}$, or a dual-source vapor deposition technique to fabricate a planar heterojunction solar cell $[4,5]$. Then, a planar structured PSC using a polyethyleneimine ethoxylated modified ITO electrode, yttrium-doped $\mathrm{TiO}_{2}$ layer, mixed halide perovskite $\mathrm{CH}_{3}$ $\mathrm{NH}_{3} \mathrm{PbI}_{3-x} \mathrm{Cl}_{x}$ absorber, and spiro-OMeTAD reached a PCE of $19.3 \%$ [6]. Very recently, triple Cs/MA/formamidinium cation PSCs reached a power output of $21.1 \%$ [7].

Currently, the most research PSC devices employ gold as a back contact, in conjunction with organic hole 
conductors acting as electron-blocking or hole transport layers [4-7]. These cells are expensive because of the high cost of pure hole transportation materials. Besides, hole conductors such as the widely used spiro-OMeTAD are not only expensive but can cause moisture-induced degradation in PSCs, especially with hygroscopic dopants such as lithium bis(trifluoromethanesulfonyl)imide [8]. To overcome the lifetime-limiting problems with the organic hole transporters, HTM-free perovskite photovoltaics were proposed and reported by Etgar et al. [9]. HTM-free PSCs achieved efficiencies of about $10 \%$ with gold as a back electrode [10-12]. The precious Au electrode also requires a high-vacuum and high-cost evaporation technique, thereby limiting its future application. Nowadays, the efficiency of the best PSCs is competitive with current commercial technologies, and they are potentially much cheaper. However, commercial solar cells must last 20-30 years with minimal degradation. The biggest challenge facing PSCs is long-term stability in a wide range of environments [7].

Low-cost nano-carbon can be an ideal material to substitute $\mathrm{Au}$ as a back contact in PSCs because its function is similar to that of Au. In the past decade, carbon nanomaterials have been demonstrated to be excellent counterelectrode candidates for use in dye-sensitized solar cells (DSSCs) owing to their various fascinating properties, including high electrical conductivity, thermal stability, good optical transparency, unique nanostructure, excellent electrocatalytic activity, low cost, and abundance [13-16]. Substantial gains have been made in the application of carbon nanomaterials in DSSCs; however, perovskite organic lead iodide is unstable at high temperatures or in some solvents [17]. Thus, the direct preparation of a carbon layer faces some problems. HTM-free PSCs with carbon contacts were first fabricated by infiltrating $\mathrm{CH}_{3} \mathrm{NH}_{3} \mathrm{PbI}_{3}$ or a mixed-cation 5-ammoniumvaleric (5-AVA) and MA perovskite (5-AVA) $)_{x}(\mathrm{MA})_{1-x} \mathrm{PbI}_{3}$ into a high-temperature prefabricated monolithic device, which consists of four layers including $\mathrm{TiO}_{2}$ dense, $\mathrm{TiO}_{2}$ mesoporous, $\mathrm{ZrO}_{2}$ mesoporous, and carbon layers [18]. The (5-AVA) $x_{x}$ (MA) ${ }_{1-x} \mathrm{PbI}_{3}$ perovskite device achieved a PCE of $12.8 \%$. The cells have shown promising stability under long-term light soaking and long-term heat exposure. But these devices employed complex structures and required processing temperatures of up to $400{ }^{\circ} \mathrm{C}$ to remove solvents and organic binders in the printed $\mathrm{ZrO}_{2}$ space and carbon black/graphite electrodes. The complicated fabrication and high-temperature processing increased material or energy consumption and limited their mass production and fabrication on a plastic substrate. Very recently, carbon counter electrodes were prepared using low-temperature (LT) processed $\left(70-100^{\circ} \mathrm{C}\right)$ carbon pastes and applied in HTMfree perovskite/ $/ \mathrm{TiO}_{2}$ heterojunction solar cells to substitute noble metallic anodes. Under optimized conditions, a PCE in the range of 8.31-9.00\% has been demonstrated with these carbon counter electrodes [19, 20]. The HTM-free solar cell with the LT carbon counter electrode can have a much simpler structure, thereby reducing the cost and improving the overall stability of PSCs. However, the PSCs based on the LT carbon contact are poor in photovoltaic performance. Therefore, it is worth developing and improving the performance of HTM-free and carbon-based PSCs.

The perovskite layers with a well-defined grain structure, full surface coverage, and small surface roughness allow realization of an efficient solar cell [5, 21]. Therefore, various morphology control protocols including sequential deposition [4], thermal evaporation deposition [5], compositional engineering [22, 23], additiveassisted deposition [24, 25], solvent engineering [26-28], and intramolecular exchange processing [7] were investigated for high-quality perovskite absorbers. Jeon et al. [26] reported a solvent engineering method for highly uniform $\mathrm{CH}_{3} \mathrm{NH}_{3} \mathrm{~Pb}\left(\mathrm{I}_{1-x} \mathrm{Br}_{x}\right)_{3} \quad(x=0.1-0.15)$ perovskite layers and high-efficiency organic HTM-based devices using a mixed solvent of $\gamma$-butyrolactone (GBL) and dimethyl sulfoxide (DMSO) followed by toluene (TO) drop-casting (DC). Although DMSO-based solvent engineering $[26,28]$ is a very potential experimental technique, the related processing involves the anfractuous coupling of fluid rheology, solvent evaporation, and molecular self-assembly, and the formation of high-quality perovskite film is the result of a complex dynamic process still under investigation. Furthermore, the morphology control methods have been mainly developed for organic HTM-based PSCs and rarely explored for HTMfree PSCs. However, the ideal morphology of HTM-free PSC also requires a uniform, highly crystalline, and highcoverage perovskite capping layer on the top of the mesoporous $\mathrm{TiO}_{2}$ [29].

In this work, we report a chlorobenzene (CB)-based solvent-assisted process toward synthesizing simple, stable, and efficient HTM-free PSCs with carbon counter electrodes. $\mathrm{CH}_{3} \mathrm{NH}_{3} \mathrm{PbI}_{3}$ absorber layers were synthesized on mesoporous $\mathrm{TiO}_{2}$ films via spin-coating the mixed solution of $\mathrm{CH}_{3} \mathrm{NH}_{3} \mathrm{I}, \mathrm{PbI}_{2}, \mathrm{GBL}$, and DMSO, followed by DC CB or TO while spinning. TO was studied as a DC solvent for comparison. The effects of the DC solvent and the annealing temperature on thin film morphology, crystal structure, and the solar cell performance were investigated. Through changing the DC solvent and optimizing the annealing temperature, extremely uniform and dense perovskite capping layers atop mesoporous $\mathrm{TiO}_{2}$ films were obtained, enabling the fabrication of remarkably improved HTM-free PSCs. The efficiency of simple structured HTMfree solar cells was high up to $11.42 \%$. The obtained 
carbon-based PSC devices have shown much more promising stability than the HTM devices.

\section{Experimental Section}

\subsection{Materials}

Unless specified, all materials were purchased from either Alfa Aesar or Sigma-Aldrich and used as received. SpiroMeOTAD was purchased from Merck KGaA and Luminescence Technology Corp. MA iodide (MAI) $\mathrm{CH}_{3} \mathrm{NH}_{3} \mathrm{I}$ was synthesized according to a previous study [30].

\subsection{Device Fabrication}

Fluorine-doped tin oxide-coated glass (Pilkington TEC 15) was patterned by etching with $\mathrm{Zn}$ powder and $2 \mathrm{M} \mathrm{HCl}$. The etched substrate was then cleaned with surfactant and rinsed with acetone, ethanol, and deionized water. A 50-nm-thick compact $\mathrm{TiO}_{2}\left(c-\mathrm{TiO}_{2}\right)$ thin layer was synthesized by a procedure reported in our previous work [31]. The porous $\mathrm{TiO}_{2}\left(p-\mathrm{TiO}_{2}\right)$ layer was deposited by spincoating at $5000 \mathrm{rpm}$ for $30 \mathrm{~s}$ using a commercial $\mathrm{TiO}_{2}$ paste (Dyesol 18NR-T) diluted in ethanol (1:2.5 weight ratio) and consequently heated at $500{ }^{\circ} \mathrm{C}$ for $30 \mathrm{~min}$. After cooling to room temperature, the as-prepared nanoporous $\mathrm{TiO}_{2}$ films were then dipped into a $40 \mathrm{mM} \mathrm{TiCl} 4$ aqueous solution for $30 \mathrm{~min}$ at $70{ }^{\circ} \mathrm{C}$, dried at ambient atmosphere, and then sintered at $500{ }^{\circ} \mathrm{C}$ for $30 \mathrm{~min}$.

$\mathrm{CH}_{3} \mathrm{NH}_{3} \mathrm{PbI}_{3}$ perovskite absorber layers were synthesized by modifying the solvent engineering method reported by Jeon et al. [26]. This was done in a glove box maintaining $10 \% \mathrm{RH}$ level. The synthesized $\mathrm{CH}_{3} \mathrm{NH}_{3} \mathrm{I}$ $(0.1975 \mathrm{~g})$ powders and lead iodide $\mathrm{PbI}_{2}(0.5785 \mathrm{~g})$ were stirred in a mixture of GBL $(700 \mu \mathrm{L})$ and DMSO (300 $\mu \mathrm{L})$ at $60{ }^{\circ} \mathrm{C}$ for $12 \mathrm{~h}$. The formed precursor solution was deposited onto $p$ - $\mathrm{TiO}_{2} / c-\mathrm{TiO}_{2} / \mathrm{FTO}$ substrate by a successive two-step spin-coating process at $2000 \mathrm{rpm}$ for $50 \mathrm{~s}$ and at $3500 \mathrm{rpm}$ for $50 \mathrm{~s}$, respectively. During the second step, anhydrous CB or TO was dripped onto the center of the sample $30 \mathrm{~s}$ prior to the end of the program. The perovskite precursor-coated substrate was heated and dried on a hot plate at a temperature of $50-140{ }^{\circ} \mathrm{C}$ for $10 \mathrm{~min}$.

The carbon electrodes were prepared by doctor blade coating an LT conductive carbon ink (Shanghai Materwin New Materials Co., Ltd.) on the grown perovskite absorber, followed by drying at $100{ }^{\circ} \mathrm{C}$ for $30 \mathrm{~min}$. For comparison, spiro-OMeTAD was deposited onto the perovskite absorber, and the metal cathode around $100 \mathrm{~nm}$ was deposited on the spiro-OMeTAD HTM layer by thermal evaporation under the base pressure of $6 \times 10^{-4} \mathrm{~Pa}[31,32]$.

\subsection{Characterization}

The morphologies of the perovskite absorbers using different post-heating temperatures and various DC solvents were characterized by field emission scanning electron microscope (FESEM, Hitachi S4800). The structures of the formed perovskite absorbers were identified by X-ray diffractometer (XRD, Bruker D8 Davinci instrument, $\mathrm{Cu}$ $\mathrm{K} \alpha: \lambda=0.15406 \mathrm{~nm})$. Photocurrent density-voltage $(J-V)$ measurements were performed using an AM 1.5 solar simulator equipped with a $1000 \mathrm{~W}$ xenon lamp (Model No. 91192, Oriel, USA). The solar simulator was calibrated using a standard silicon cell (Newport, USA). The light intensity was $100 \mathrm{~mW} \mathrm{~cm}^{-2}$ on the surface of the test cell. $J-V$ curves were measured using a computer-controlled digital source meter (Keithley 2440) in the reverse direction. During device photovoltaic performance characterization, a metal aperture mask with an opening of about $0.09 \mathrm{~cm}^{2}$ was used.

\section{Results and Discussion}

Initially, we investigated the effect of DC solvent on the morphology of $\mathrm{CH}_{3} \mathrm{NH}_{3} \mathrm{PbI}_{3}$ perovskite film grown on the $p-\mathrm{TiO}_{2}$ via the solvent engineering method. The postheating temperature for the $\mathrm{CH}_{3} \mathrm{NH}_{3} \mathrm{PbI}_{3}$ absorber is $100{ }^{\circ} \mathrm{C}$. Figure 1 shows the optical and SEM images of $\mathrm{CH}_{3} \mathrm{NH}_{3} \mathrm{PbI}_{3}$ layers fabricated without DC solvent or with $\mathrm{CB}$ or TO as a DC solvent. For the sample without using DC solvent, non-homogeneous perovskite film was formed, and rather large branch-like grains with a significant portion of the substrate (the $p-\mathrm{TiO}_{2}$ layer) being exposed without $\mathrm{CH}_{3} \mathrm{NH}_{3} \mathrm{PbI}_{3}$ coverage are seen in Fig. 1a, b, which is in accordance with previous observations [5, 33]. A higher magnification SEM image of these large branch-like grains reveals that the grain structure consists of crystals with sizes of $50-400 \mathrm{~nm}$ as shown in the inset of Fig. 1b. Crystals of the semiconductor perovskite $\mathrm{CH}_{3} \mathrm{NH}_{3} \mathrm{PbI}_{3}$ with a wide range of sizes were also reported when the perovskite was deposited by a single-step spin-coating from a solution of $\mathrm{CH}_{3} \mathrm{NH}_{3} \mathrm{I}$ and $\mathrm{PbI}_{2}$ in GBL or $N, N$-dimethylformamide (DMF) [4]. When TO was used as a DC solvent, the large branch-like grains disappeared in the optical image in Fig. 1c, and some smaller $(35-140 \mathrm{~nm})$ and more uniform crystals started to form, leading to reduced pinhole sizes and enhanced surface coverage of perovskites as shown in Fig. 1d. In contrast, when CB was used as a DC solvent, the mesoporous $\mathrm{TiO}_{2}$ layer was covered with interconnected crystals with a full surface coverage as clearly shown in the inset of Fig. 1f. The $\mathrm{CH}_{3} \mathrm{NH}_{3} \mathrm{PbI}_{3}$ films formed by the addition of $\mathrm{CB}$ are composed of sub-micron 

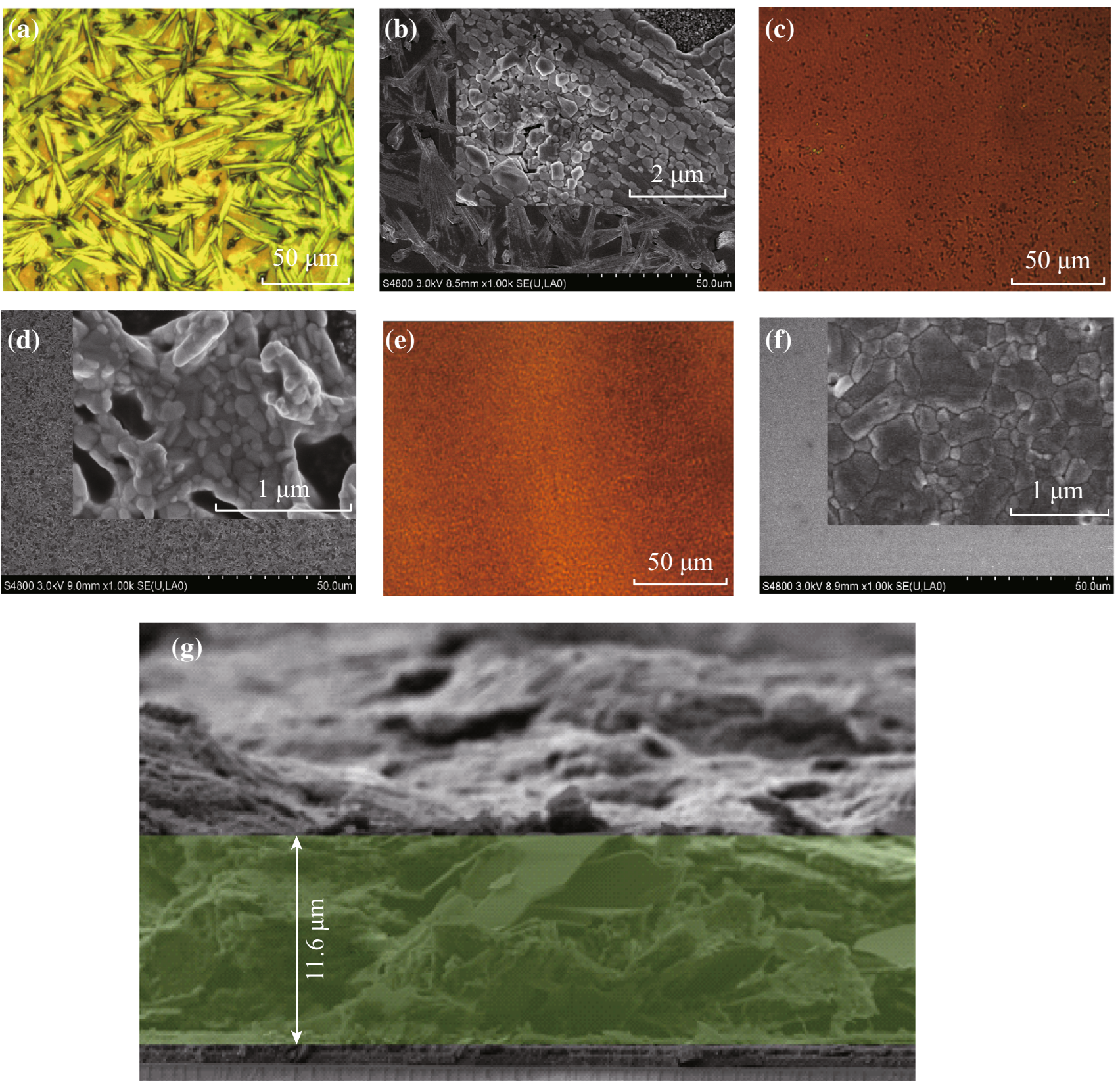

Fig. 1 Optical and SEM images of $\mathrm{CH}_{3} \mathrm{NH}_{3} \mathrm{PbI}_{3}$ layers fabricated without drop-casting solvent $(\mathbf{a}, \mathbf{b})$ or with toluene $(\mathbf{c}, \mathbf{d})$ or chlorobenzene $(\mathbf{e}$, f) as a drop-casting solvent. (g) Cross-section FESEM image of the PSCs

(100-550 nm)-sized grains, which are obviously larger than those in the absorber layer using TO as a DC solvent. For the former, the top surface exhibits a dense-grained morphology. The differences in the surface coverages of perovskite films on the $p$ - $\mathrm{TiO}_{2}$ layer likely affect the device characteristics $[29,34]$. The cross-section FESEM image of the PSCs is shown in Fig. 1g. The formed carbon film is very thick compared to the other functional layers in the device. The thickness of the carbon layer is about $11.6 \mu \mathrm{m}$. Its sheet resistance is about $14.6 \Omega \mathrm{sq}^{-1}$. The carbon film achieved good and tight adhesion to the underlayered $\mathrm{CH}_{3} \mathrm{NH}_{3} \mathrm{PbI}_{3}$ and provided complete coverage over the absorber.

The XRD patterns of the above three samples are shown in Fig. 2. The red, blue, and purple curves indicate XRD spectra measured from $\mathrm{CH}_{3} \mathrm{NH}_{3} \mathrm{PbI}_{3}$ layers without DC solvent and with $\mathrm{CB}$ or $\mathrm{TO}$ as the DC solvent, respectively. Diffraction peaks observed at $14.02^{\circ}, 28.32^{\circ}, 31.76^{\circ}$, $40.46^{\circ}$, and $43.02^{\circ}$ correspond to the reflections from (110), (220), (310), (224), and (314) crystal planes of the tetragonal perovskite structure, respectively $[35,36]$. It was observed that compared to the case of the pristine absorber 


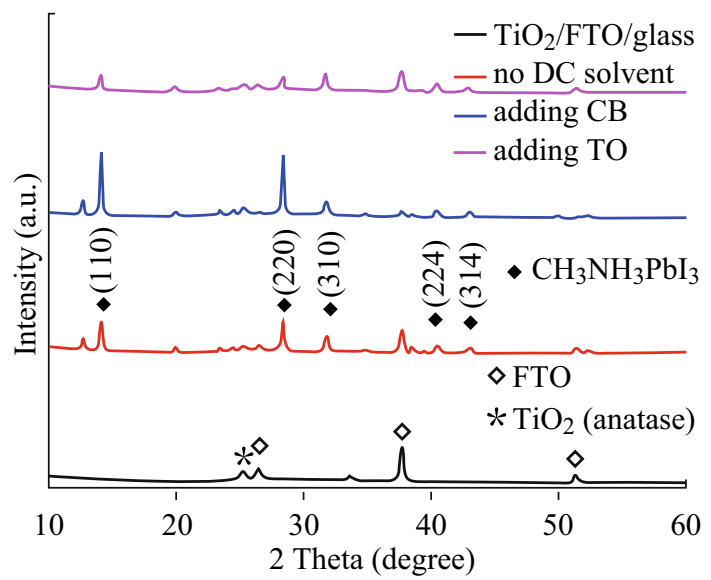

Fig. 2 XRD spectra of $\mathrm{CH}_{3} \mathrm{NH}_{3} \mathrm{PbI}_{3}$ layers fabricated without dropcasting (DC) solvent or with chlorobenzene (CB) or toluene (TO) as a DC solvent

without DC solvent modification, intense diffraction peaks on both the (110) and (220) facets became significantly enhanced with the addition of $\mathrm{CB}$, indicative of the improvements in the crystalline property of the $\mathrm{CH}_{3} \mathrm{NH}_{3-}$ $\mathrm{PbI}_{3}$ film. Also, the optical and SEM images indicate the enlarged crystalline domains in the lateral direction with the morphology evolution from branch like to plate like (Fig. 1). However, compared to the case without DC solvent, both (110) and (220) peaks became obviously reduced with the addition of $\mathrm{TO}$, which can be attributed to the reduced quality of the perovskite crystals in the latter as shown in the inset of Fig. 1b, d.

To investigate the effect of the additional solvent on the HTM-free device performance, carbon electrode-based PSCs were fabricated without DC solvent or with CB or $\mathrm{TO}$ as a DC solvent. The post-heating temperature for the $\mathrm{CH}_{3} \mathrm{NH}_{3} \mathrm{PbI}_{3}$ absorber is $100{ }^{\circ} \mathrm{C}$. For each device fabrication condition, 8-12 PSCs were fabricated in an identical

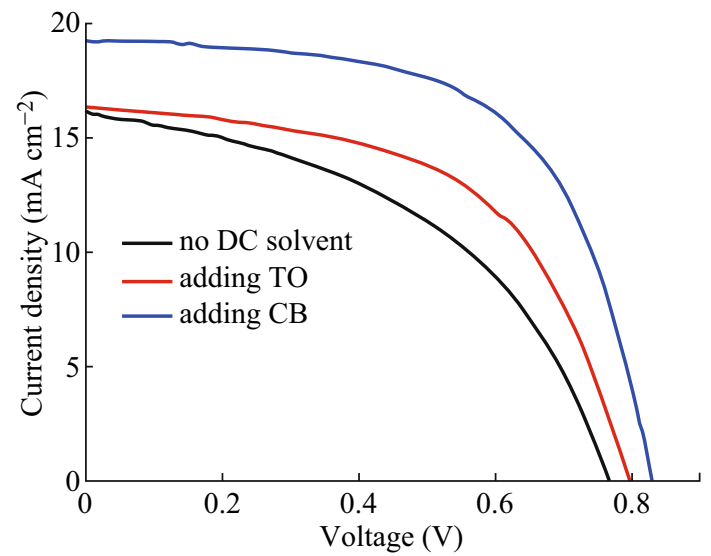

Fig. $3 J-V$ curves for carbon-based solar cells with $\mathrm{CH}_{3} \mathrm{NH}_{3} \mathrm{PbI}_{3}$ layers fabricated without drop-casting (DC) solvent or with chlorobenzene (CB) or toluene (TO) as a DC solvent manner. The average device characteristics are shown in Fig. 3. The corresponding photovoltaic parameters including short circuit current density $\left(J_{\mathrm{SC}}\right)$, open circuit voltage $\left(V_{\mathrm{OC}}\right)$, PCE, and fill factor $(\mathrm{FF})$ are listed in Table 1. As shown in Fig. 3 and Table 1, the PSC with the pristine perovskite film showed a $J_{\mathrm{SC}}$ of $16.10 \mathrm{~mA} \mathrm{~cm}{ }^{-2}$, a $V_{\mathrm{OC}}$ of $0.77 \mathrm{~V}$, and an FF of 0.46 , therefore an overall PCE of $5.70 \%$. Using TO droplets, the fabricated device showed an enhanced $V_{\mathrm{OC}}$ of $0.80 \mathrm{~V}$, an FF of 0.55 , and a similar $J_{\mathrm{SC}}$ of $16.31 \mathrm{~mA} \mathrm{~cm}^{-2}$, thus an improved PCE of $7.17 \%$, leading to about $26 \%$ enhancement of PCE. Remarkably, through the introduction of $\mathrm{CB}$ into the perovskite precursor layer, the PCE increased to $9.73 \%$. The introduction of $\mathrm{CB}$ droplets resulted in a simultaneous improvement of all the device parameters, e.g., $J_{\mathrm{SC}}$ increased from 16.10 to $19.21 \mathrm{~mA} \mathrm{~cm}{ }^{-2}, V_{\mathrm{OC}}$ from 0.77 to $0.83 \mathrm{~V}$, and FF from 0.46 to 0.61 , and thus about $71 \%$ enhancement of PCE in the device.

The morphology and the crystal structure evolution of the perovskite film with $\mathrm{CB}$ droplet treatment shown in Figs. 1 and 2 could be attributed to the formation of $\mathrm{CH}_{3} \mathrm{NH}_{3} \mathrm{I}-\mathrm{PbI}_{2}-\mathrm{DMSO}$ intermediate phase during spincoating from MAI, $\mathrm{PbI}_{2}$, and DMSO [26]. This process can be regarded as the transformation of $\mathrm{PbI}_{2}-\mathrm{DMSO}-\mathrm{MAI}$ into $\mathrm{MAPbI}_{3}$, similar to the case with a TO DC. Jeon et al. [26] deposited high-quality $\mathrm{CH}_{3} \mathrm{NH}_{3} \mathrm{~Pb}\left(\mathrm{I}_{1-x} \mathrm{Br}_{x}\right)_{3}$ $(x=0.1-0.15)$ perovskite layers through the use of a combination of DMSO/GBL followed by a TO drip. They found that the spin-coated $\mathrm{PbI}_{2}-\mathrm{DMSO}-\mathrm{MAI}$ intermediate phase possessed an extremely uniform and flat morphology, the intermediate phase was partly transformed into perovskite phases at $100{ }^{\circ} \mathrm{C}$, and the complete transformation into $\mathrm{CH}_{3} \mathrm{NH}_{3} \mathrm{~Pb}\left(\mathrm{I}_{1-x} \mathrm{Br}_{x}\right)_{3}$ took place at an annealing temperature of $130{ }^{\circ} \mathrm{C}$. But, from Fig. 2, pure perovskite phases were obtained at $100{ }^{\circ} \mathrm{C}$ for treatment with both $\mathrm{CB}$ and $\mathrm{TO}$ in our synthesis. Our results are in accordance with those reported in [27]. High-quality $\mathrm{CH}_{3} \mathrm{NH}_{3} \mathrm{PbI}_{3}$ films were obtained for a fast depositioncrystallization procedure at $100{ }^{\circ} \mathrm{C}$ with the assistance of $\mathrm{CB}$ in the latter.

Thermal energy directly dominates the thermodynamics of the crystalline perovskite film formation in solution processes. Controlling the thermal annealing process for the perovskite precursor film is a key to achieving high performance $[17,34]$. In this work, we found that annealing temperature plays an important role in the quality of the perovskite absorber. Figure 4 shows the XRD patterns of the perovskite films grown on the $p-\mathrm{TiO}_{2}$ via the solventassisted method with different annealing temperatures. The $\mathrm{CH}_{3} \mathrm{NH}_{3} \mathrm{PbI}_{3}$ layers were fabricated with $\mathrm{CB}$ treatment. The post-heating temperature was changed from 50 to $140{ }^{\circ} \mathrm{C}$. When a low annealing temperature of $50{ }^{\circ} \mathrm{C}$ was used, XRD peaks at the low angles of $7.21^{\circ}$ and $9.17^{\circ}$ can 
Table 1 Photovoltaic performance of solar cells with $\mathrm{CH}_{3} \mathrm{NH}_{3} \mathrm{PbI}_{3}$ layers fabricated without assisted solvent or with chlorobenzene or toluene as an assisted solvent

\begin{tabular}{lllllrr}
\hline Samples & $J_{\mathrm{SC}}\left(\mathrm{mA} \mathrm{cm}^{-2}\right)$ & $V_{\mathrm{OC}}(\mathrm{V})$ & FF & PCE $(\%)$ & $R_{\mathrm{S}}\left(\Omega \mathrm{cm}^{2}\right)$ & $R_{\mathrm{SH}}\left(\Omega \mathrm{cm}^{2}\right)$ \\
\hline No drop-casting solvent & 16.10 & 0.77 & 0.46 & 5.70 & 129 & 1996 \\
Adding toluene & 16.31 & 0.80 & 0.55 & 7.17 & 121 & 4601 \\
Adding chlorobenzene & 19.21 & 0.83 & 0.61 & 9.73 & 73 & 11,175 \\
\hline
\end{tabular}

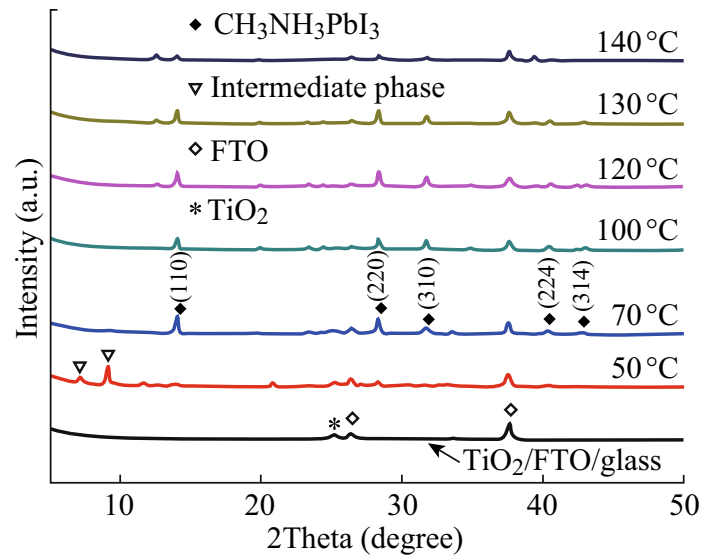

Fig. 4 XRD patterns of the perovskite films grown on the $p-\mathrm{TiO}_{2}$ via chlorobenzene drop-casting at different annealing temperatures of $50-140{ }^{\circ} \mathrm{C}$

be attributed to the MAI-PbI - DMSO intermediate phase in the film [26]. When the annealing temperature was increased to $70^{\circ} \mathrm{C}$, only a very weak peak at $9.17^{\circ}$ was observed. When the annealing temperature was equal to or greater than $100{ }^{\circ} \mathrm{C}$, XRD peaks at the low angles disappeared completely. Besides, when the annealing temperature was equal to or greater than $70{ }^{\circ} \mathrm{C}$, peaks at $14.02^{\circ}$, $28.32^{\circ}, 31.76^{\circ}, 40.46^{\circ}$, and $43.02^{\circ}$, corresponding to the reflections from (110), (220), (310), (224), and (314) crystal planes of the tetragonal perovskite structure, respectively [35, 36], were detected. The XRD results indicated that the MAI- $-\mathrm{PbI}_{2}-\mathrm{DMSO}$ intermediate phase was fully transformed into perovskite phases at $100{ }^{\circ} \mathrm{C}$ for our pure halide material system with CB DC. Moreover, a small peak at $12.66^{\circ}$, which is associated with the $\mathrm{PbI}_{2}$ film, is visible in the XRD pattern for the absorber formed at $120-140{ }^{\circ} \mathrm{C}$. The intensity of this $\mathrm{PbI}_{2}$ phase peak increased with the temperature rising from 120 to $140{ }^{\circ} \mathrm{C}$, while the perovskite phase peaks decreased with the temperature increase. It is worth mentioning that annealing at $120{ }^{\circ} \mathrm{C}$ brought about majority of the conversion of the precursor film to the active perovskite phase and retention of a small fraction of $\mathrm{PbI}_{2}$, as exhibited by the small peak at $12.66^{\circ}$. Although this peak expresses incomplete conversion of the $\mathrm{PbI}_{2}-\mathrm{DMSO}-\mathrm{MAI}$ film to active perovskite phase, the presence of a little residual $\mathrm{PbI}_{2}$ has been found to be advantageous for device performance [37, 38], likely due to passivation of surface and grain boundary states [37].

Figure 5 shows the optical and SEM images of the perovskite films grown on the $p-\mathrm{TiO}_{2}$ via the solvent-assisted method with various annealing temperatures of $120-140{ }^{\circ} \mathrm{C}$ and CB DC. Annealing at $120{ }^{\circ} \mathrm{C}$ resulted in the formation of plate-like, uniform, and well-crystallized perovskite layer. The entire layer is composed of homogeneous, interconnected, and perfectly crystallized crystals with $100 \%$ surface coverage atop the $p-\mathrm{TiO}_{2}$ shown in the inset of Fig. 5b. The perfect absorber layer is composed of sub-micron (250-750 nm)-sized grains, which are more uniform and larger than those in the $\mathrm{CH}_{3} \mathrm{NH}_{3} \mathrm{PbI}_{3}$ film formed with $\mathrm{CB}$ treatment and an annealing temperature of $100{ }^{\circ} \mathrm{C}$ shown in Fig. 1e, f. When the annealing temperature increased further from $120{ }^{\circ} \mathrm{C}$, however, the quality of the resulted absorber degraded and the surface coverage of perovskites decreased. At $130{ }^{\circ} \mathrm{C}$, the grown absorber layer is composed of sub-micron-sized grains with some portion of the $p-\mathrm{TiO}_{2}$ layer being exposed without $\mathrm{CH}_{3} \mathrm{NH}_{3} \mathrm{PbI}_{3}$ coverage as clearly shown in the inset of Fig. 5d. Annealing at $140{ }^{\circ} \mathrm{C}$ led to larger pinhole sizes and lower surface coverage of perovskites as evidenced in the inset of Fig. 5f.

To investigate the effect of annealing temperature on the HTM-free device performance, PSCs were fabricated with $\mathrm{CH}_{3} \mathrm{NH}_{3} \mathrm{PbI}_{3}$ absorbers obtained via DC CB and annealing at different temperatures from 100 to $140{ }^{\circ} \mathrm{C}$. For each temperature, $8-12$ PSCs were fabricated in an identical manner. The average device characteristics are presented in Fig. 6, the corresponding photovoltaic parameters of which are summarized in Table 2. A clear correlation was observed between the annealing temperature of the perovskite and the photovoltaic performance of the device. Samples fabricated at $120{ }^{\circ} \mathrm{C}$ exhibited the highest PCE, $11.44 \%$, as a result of the $J_{\mathrm{SC}}, V_{\mathrm{OC}}$, and $\mathrm{FF}$, $21.43 \mathrm{~mA} \mathrm{~cm}^{-2}, 0.89 \mathrm{~V}$, and 0.60 , respectively. Devices grown at $130{ }^{\circ} \mathrm{C}$ also exhibited a quite high PCE of $10.21 \%$, as a result of the $J_{\mathrm{SC}}, V_{\mathrm{OC}}$, and $\mathrm{FF}$, $19.29 \mathrm{~mA} \mathrm{~cm}^{-2}, 0.84 \mathrm{~V}$, and 0.63 , respectively. But, as the annealing temperature was increased further above $130{ }^{\circ} \mathrm{C}$, 

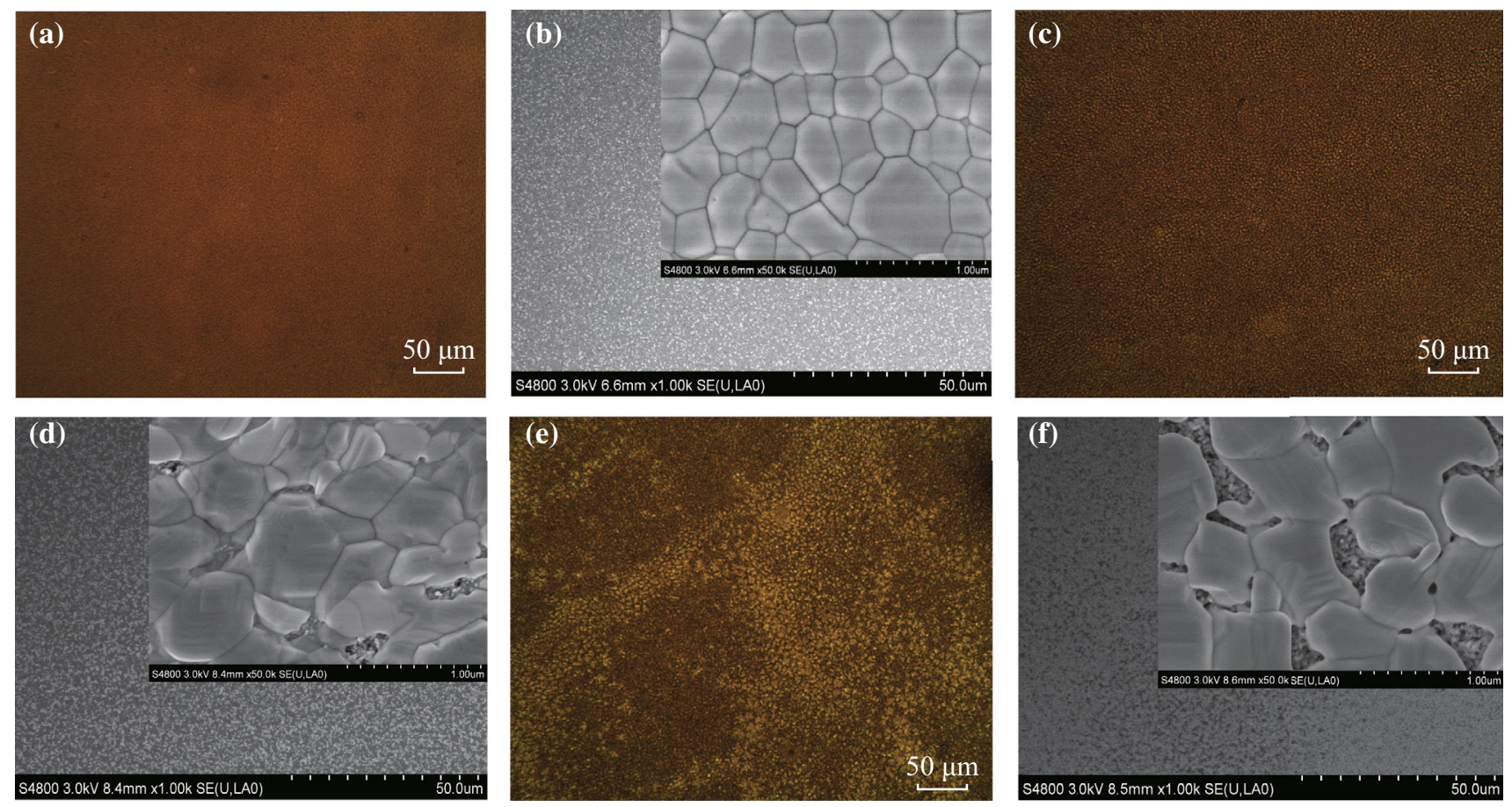

Fig. 5 Optical and SEM images of the perovskite films grown on the $p-\mathrm{TiO}_{2}$ via chlorobenzene drop-casting at different annealing temperatures: a, b $120^{\circ} \mathrm{C}, \mathbf{c}, \mathbf{d} 130{ }^{\circ} \mathrm{C}$, and e, f $140{ }^{\circ} \mathrm{C}$

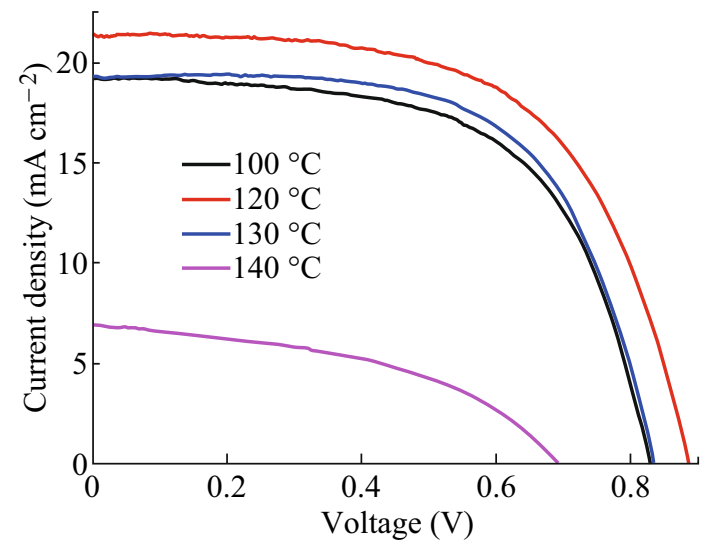

Fig. $6 J-V$ curves for the solar cells with $\mathrm{CH}_{3} \mathrm{NH}_{3} \mathrm{PbI}_{3}$ layers fabricated via chlorobenzene drop-casting at different annealing temperatures of $120-140{ }^{\circ} \mathrm{C}$

the $J_{\mathrm{SC}}, V_{\mathrm{OC}}$, and $\mathrm{FF}$ values considerably decreased, leading to a dramatic fall in PCE. The best photovoltaic performance of the device with $120^{\circ} \mathrm{C}$ can be mainly associated with the highest crystalline, morphological, and surface coverage quality of its absorber shown in Figs. 4 and 5. These experimental observations are consistent with the results reported in [17, 34]. The corresponding monochromatic incident photon-to-electron conversion efficiency (IPCE) spectra of these four devices are shown in Fig. 7. Aside from the PSCs with an annealing temperature of $140{ }^{\circ} \mathrm{C}$, the other three exhibited broad and efficient photoelectric conversion covering the range of visible light. Especially, the devices with 120 and $130{ }^{\circ} \mathrm{C}$ achieved much higher IPCEs than the cell with $140{ }^{\circ} \mathrm{C}$ over the whole spectral range between 300 and $800 \mathrm{~nm}$, matching the difference in photocurrents obtained for these devices shown in Fig. 6 and Table 2.

Moreover, the series resistance $\left(R_{\mathrm{S}}\right)$ and the shunt resistance $\left(R_{\mathrm{SH}}\right)$ were estimated from the $J-V$ characteristics shown in Figs. 3 and 6 . The $R_{\mathrm{S}}$ and $R_{\mathrm{SH}}$ data are summarized in Tables 1 and 2. For solar cells, maintaining the $R_{\mathrm{S}}$ as low as possible is vitally important because large $R_{\mathrm{S}}$ will decrease $J_{\mathrm{SC}}, V_{\mathrm{OC}}$, and FF and consequently PCEs $[31,39,40]$. For the devices with $100{ }^{\circ} \mathrm{C}$, the $R_{\mathrm{S}}$ from the PSC with the addition of CB is $73 \Omega \mathrm{cm}^{2}$, which is smaller than 121 or $129 \Omega \mathrm{cm}^{2}$ from the device with the introduction of TO or without DC solvent, respectively. In the case of the CB treatment, when the temperature was increased from 100 to $130{ }^{\circ} \mathrm{C}$, the $R_{\mathrm{S}}$ remained at the low values of about $70 \Omega \mathrm{cm}^{2}$. But, when the temperature was increased up to $140{ }^{\circ} \mathrm{C}$, the $R_{\mathrm{S}}$ of the device increased to $293 \Omega \mathrm{cm}^{2}$. The low $R_{\mathrm{S}}$ from the device with the addition of $\mathrm{CB}$ and the annealing temperatures of $100-130{ }^{\circ} \mathrm{C}$ is due to small contact resistance and low bulk resistance of the high-quality perovskite layer, indicating that high currents can flow through the cell at low applied voltages [39]. Typically, the shunt resistance $\left(R_{\mathrm{SH}}\right)$ is due to $\mathrm{p}-\mathrm{n}$ junction 
Table 2 Photovoltaic performance of solar cells with $\mathrm{CH}_{3} \mathrm{NH}_{3} \mathrm{PbI}_{3}$ layers fabricated via assistance of chlorobenzene at different annealing temperatures of $120-140{ }^{\circ} \mathrm{C}$

\begin{tabular}{llllccc}
\hline Annealing $T\left({ }^{\circ} \mathrm{C}\right)$ & $J_{\mathrm{SC}}\left(\mathrm{mA} \mathrm{cm}^{-2}\right)$ & $V_{\mathrm{OC}}(\mathrm{V})$ & $\mathrm{FF}(\%)$ & PCE $(\%)$ & $R_{\mathrm{S}}\left(\Omega \mathrm{cm}^{2}\right)$ & $R_{\mathrm{SH}}\left(\Omega \mathrm{cm}^{2}\right)$ \\
\hline 100 & 19.21 & 0.83 & 0.61 & 9.73 & 73 & 11,175 \\
120 & 21.43 & 0.89 & 0.60 & 11.44 & 74 & 18,808 \\
130 & 19.29 & 0.84 & 0.63 & 10.21 & 70 & 22,404 \\
140 & 6.93 & 0.69 & 0.45 & 2.15 & 293 & 3495 \\
\hline
\end{tabular}

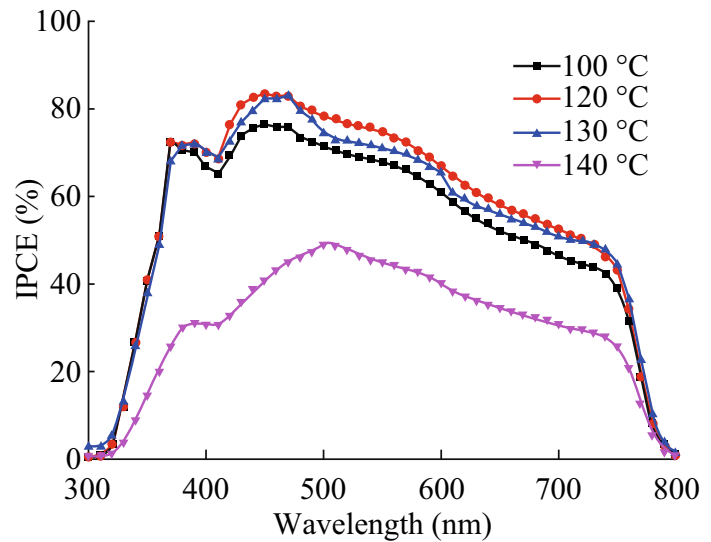

Fig. 7 IPCE spectra of the solar cells with $\mathrm{CH}_{3} \mathrm{NH}_{3} \mathrm{PbI}_{3}$ layers fabricated via chlorobenzene drop-casting at different annealing temperatures of $120-140{ }^{\circ} \mathrm{C}$

non-idealities and impurities near the junction, which bring about partial shorting of the junction, especially near cell edges. The $R_{\mathrm{SH}}$ must be higher to avoid current loss at the junction [40], dwindling the photocurrent and consequently the solar cell performance. It has been diffusely reported that the pinholes formed in the solution-processed $\mathrm{CH}_{3}$ $\mathrm{NH}_{3} \mathrm{PbI}_{3-x} \mathrm{Cl}_{x}$ absorbers can cause direct contact between the $p$-type spiro-OMeTAD and the $\mathrm{TiO}_{2}$ compact layer, leading to a shunting path that is probably partially responsible for the low FF and open circuit voltage in devices $[5,17]$. In the case of our HTM-free PSCs with $100{ }^{\circ} \mathrm{C}$ shown in Table 1 , the pinhole or voids in the capping layer on the $p-\mathrm{TiO}_{2}$ layer caused the least $R_{\mathrm{SH}}$, resulting in the lowest $\mathrm{FF}$ and $V_{\mathrm{OC}}$ in the device with pristine absorber, and induced the second least $R_{\mathrm{SH}}$, leading to the second lowest FF and $V_{\mathrm{OC}}$ in the device via dropwise TO application. The smoother perovskite layer due to introducing $\mathrm{TO}$ or $\mathrm{CB}$ into the spin-coated perovskite precursor layer from the mixed solution of $\mathrm{CH}_{3} \mathrm{NH}_{3} \mathrm{I}, \mathrm{PbI}_{2}$, GBL, and DMSO decreased the series resistance and increased the shunt resistance of cell, resulting in the higher photovoltaic effects (Table 1). In the case of different annealing temperatures with the CB treatment shown in Table 2, as the temperature was increased from 100 to $130{ }^{\circ} \mathrm{C}$, the shunt $R_{\mathrm{SH}}$ had the higher and higher resistive value, but, when the temperature was increased up to $140{ }^{\circ} \mathrm{C}$, the pinhole or voids in the capping layer on the $p$ $\mathrm{TiO}_{2}$ layer caused the least $R_{\mathrm{SH}}$, resulting in the lowest FF and $V_{\mathrm{OC}}$ in the device. Therefore, the improved device performance can be associated with the evolved and promoted morphological and crystalline properties of $\mathrm{CH}_{3}$ $\mathrm{NH}_{3} \mathrm{PbI}_{3}$ film by use of $\mathrm{CB}$ or TO droplets and optimized annealing temperature, as exhibited by optical, SEM, and XRD measurements in Figs. 1, 2, 4, and 5. The improved device performance unambiguously verified the significance of CB droplets and annealing temperature on PSC optimization. The possible mechanisms for improving the quality of the perovskite absorber layer with DC solvent and enhancing the resulted PSC performance are further explored below.

The boiling points of the traditional solvents used for growing perovskite absorbers are relatively high, having the values of 153 and $204-205{ }^{\circ} \mathrm{C}$ for $N, N$-dimethylmethanamide (DMF) and GBL, respectively. Such relatively high boiling points can result in the formation of large-area thickness variations or shrinkage/dewetting of the casting precursor solution due to the relatively prolonged drying times of solution-coated films. In our work, the proposed solvent- assisted technology involved spincoating the mixed solution of $\mathrm{CH}_{3} \mathrm{NH}_{3} \mathrm{I}, \mathrm{PbI}_{2}$, and GBL/ DMSO, followed by DC CB or TO while spinning. TO (boiling point $111^{\circ} \mathrm{C}$, vapor pressure $22 \mathrm{mmHg}$ ) and $\mathrm{CB}$ (boiling point $132{ }^{\circ} \mathrm{C}$, vapor pressure $11.8 \mathrm{mmHg}$ ) have much lower boiling point and tremendously higher vapor pressure than DMSO (boiling point $189^{\circ} \mathrm{C}$, vapor pressure $0.6 \mathrm{mmHg}$ ) and GBL (boiling point $204-205^{\circ} \mathrm{C}$, vapor pressure $1.5 \mathrm{mmHg}$ ) at room temperature. Considering the physical properties of the solvents, at the beginning stage of the spin-coating process, the film was composed of MAI and $\mathrm{PbI}_{2}$ dissolved in the DMSO/GBL solvent mixture, and the precursor film continued to thin because liquid flowed radially owing to the action of centrifugal force, and solvent evaporation was neglected, while in the intermediate stage, the composition of the film was concentrated by the evaporation of GBL due to its higher vapor pressure than DMSO. Then, the introduction of TO or CB droplets with very higher vapor pressure during the second spinning stage induced the immediate freezing of the constituents on spinning and the rapid formation of the MAI- $-\mathrm{PbI}_{2}-\mathrm{DMSO}$ phase, producing a full and even precursor layer. The use of DMSO helped retard the rapid reaction between the inorganic $\mathrm{PbI}_{2}$ and $\mathrm{CH}_{3} \mathrm{NH}_{3} \mathrm{I}$ components of perovskite during the evaporation of solvents in the spin-coating 


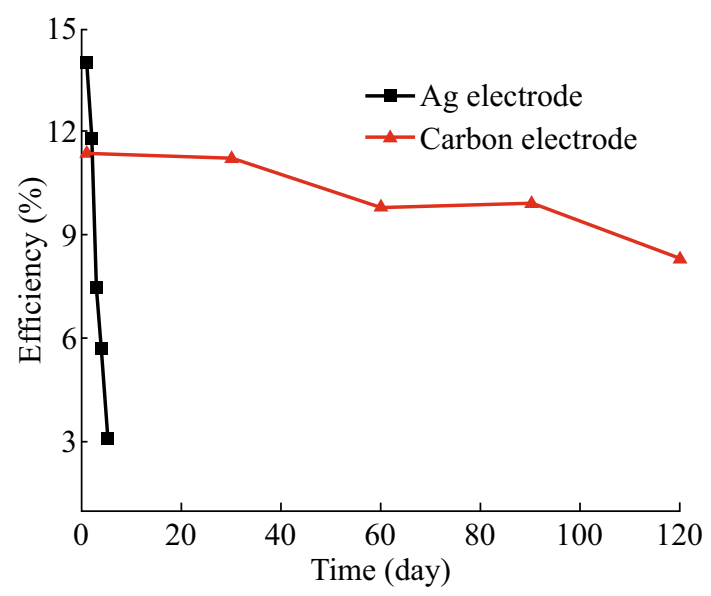

Fig. 8 Stability profile (PCE) of non-sealed $\mathrm{FTO} / c-\mathrm{TiO}_{2} / p-\mathrm{TiO}_{2} /$ $\mathrm{CH}_{3} \mathrm{NH}_{3} \mathrm{PbI}_{3} /$ spiro-MeOTAD/Ag (squares) and $\mathrm{FTO} / c-\mathrm{TiO}_{2} / p-\mathrm{TiO}_{2} /$ $\mathrm{CH}_{3} \mathrm{NH}_{3} \mathrm{PbI}_{3} /$ carbon (triangles) perovskite solar cells. The devices were kept in a dry cabinet of electronics without nitrogen $(10 \% \mathrm{RH}$, room temperature)

process because DMSO has a stronger coordination ability with $\mathrm{PbI}_{2}$ than that of the usually used DMF [41]. At last, the greatly homogeneous and flat precursor film was converted into a pure crystalline $\mathrm{CH}_{3} \mathrm{NH}_{3} \mathrm{PbI}_{3}$ perovskite layer after annealing at $100{ }^{\circ} \mathrm{C}$. As displayed in Figs. 1, 2, and 3 and Table 1, $\mathrm{CH}_{3} \mathrm{NH}_{3} \mathrm{PbI}_{3}$ films via the dropwise $\mathrm{CB}$ application showed better morphological, crystalline, and photovoltaic properties than the perovskite layers using TO droplet treatment. For a highly volatile solvent such as TO, one can expect to have very significant evaporation during the spin-off stage. The strong evaporation of the casting TO solvent possibly affects fluid rheology and vice versa $[42,43]$, tending to give relatively rough precursor films. In contrast, CB has a lower evaporation rate due to its relatively high boiling point and lower vapor pressure compared to those of TO, which should be a benefit to form a flatter, smoother, and more uniform $\mathrm{MAI}-\mathrm{PbI}_{2}-\mathrm{DMSO}$ intermediate phase layer. The higher quality intermediate phase layer resulted in more highly crystalline and more homogeneous $\mathrm{CH}_{3} \mathrm{NH}_{3} \mathrm{PbI}_{3}$ perovskite capping layer atop the $m p-\mathrm{TiO}_{2}$ after the heat treatment at $100{ }^{\circ} \mathrm{C}$, which caused the lower series resistance, higher shunt resistance, and better photovoltaic performance in the PSC (Fig. 3; Table 1). The fabricated HTM-free PSCs based on CB treatment demonstrated a PCE of $9.73 \%$, which is 71 and $36 \%$ higher than those of the control device fabricated from the pristine perovskite film or via TO droplet treatment, respectively. The improved device performance unambiguously verified the significance of CB droplets on HTM-free PSC optimization. After further optimizing the annealing temperature, the HTM-free PSCs based on the incorporation of CB achieved a PCE of $11.44 \%$.
Moreover, the fabricated HTM-free solar cells are significantly more stable than the spiro-OMeTAD HTM-based devices with Ag electrode shown in Fig. 8. The PCE of carbon-based device was over $8 \%$ after 120 days, while the efficiency of the HTM-based cell dropped to $3 \%$ only after 5 days. We hope that our findings can provide a better understanding of the crystalline perovskite film formation in solvent-assisted processes and make a contribution to the development of low-cost and stable PSCs.

\section{Conclusions}

The type of the DC solvent and annealing temperature employed during the preparation of $\mathrm{CH}_{3} \mathrm{NH}_{3} \mathrm{PbI}_{3}$ films via a solvent-assisted process have a considerable impact on the resulting absorber morphologies, crystalline structures, and device photovoltaic performance. The advantages using $\mathrm{CB}$ as an assisted solvent become apparent upon comparing the $J-V$ curves and PCEs of the carbon-based HTM-free $\mathrm{CH}_{3} \mathrm{NH}_{3} \mathrm{PbI}_{3}$ devices prepared using $\mathrm{CB}$ or TO as a DC solvent or without DC solvent. The $\mathrm{CH}_{3} \mathrm{NH}_{3} \mathrm{PbI}_{3}$ films grown using $\mathrm{CB}$ show better morphological, surface coverage, and crystalline properties than the perovskite layers formed by the addition of TO during processing under the same conditions. The pristine perovskite layers without using DC solvent exhibit the even poorer morphological and crystalline properties. The HTM-free devices based on $\mathrm{CH}_{3} \mathrm{NH}_{3} \mathrm{PbI}_{3}$ fabricated by incorporation of $\mathrm{CB}$ show superior PCEs. The effects of the annealing temperature on $\mathrm{CH}_{3} \mathrm{NH}_{3} \mathrm{PbI}_{3}$ film morphology, crystal structure, and the solar cell performance were also investigated for the CB-assisted process. High-efficiency carbon-based HTM-free solar cells with a PCE of $11.44 \%$ were produced using an optimized annealing temperature of $120{ }^{\circ} \mathrm{C}$. This work provides an effective protocol for fabricating efficient, simple, stable, and low-cost inorganic-organic hybrid heterojunction solar cells.

Acknowledgments This work was supported by the National Natural Science Foundation of China (Nos. 11274119, 61275038).

Open Access This article is distributed under the terms of the Creative Commons Attribution 4.0 International License (http://creative commons.org/licenses/by/4.0/), which permits unrestricted use, distribution, and reproduction in any medium, provided you give appropriate credit to the original author(s) and the source, provide a link to the Creative Commons license, and indicate if changes were made.

\section{References}

1. A. Kojima, K. Teshima, Y. Shirai, T. Miyasaka, Organometal halide perovskites as visible-light sensitizers for photovoltaic cells. J. Am. Chem. Soc. 131(17), 6050-6051 (2009). doi:10.1021/ja809598r 
2. H.S. Kim, C.R. Lee, J.H. Lm, K.B. Lee, T. Meohl et al., Iodide perovskite sensitized all-solid-state submicron thin film mesoscopic solar cell with efficiency exceeding 9\%. Sci. Rep. 2(8), 591-597 (2012). doi:10.1038/srep00591

3. M.M. Lee, J. Teushcer, T. Miyasaka, T.N. Murakami, H.J. Snaith, Efficient hybrid solar cells based on meso-superstructured organometal halide perovskites. Science 338(6107), 643-647 (2012). doi:10.1126/science

4. J. Burschka, N. Pellet, S.J. Moon, R.H. Baker, P. Gao, Sequential deposition as a route to high-performance perovskite-sensitized solar cells. Nature 499(7458), 316-319 (2013). doi:10.1038/ nature 12340

5. M.Z. Liu, M.B. Johnston, H.J. Snaith, Efficient planar heterojunction perovskite solar cells by vapour deposition. Nature 501(7467), 395-398 (2013). doi:10.1038/nature12509

6. H.P. Zhou, Q. Chen, G. Li, S. Luo, T. Song et al., Interface engineering of highly efficient perovskite solar cells. Science 345(6196), 542-546 (2014). doi:10.1126/science.1254050

7. M. Saliba, T. Matsui, J. Seo, K. Domanski, J. Correa-Baena et al., Cesium-containing triple cation perovskite solar cells: improved stability, reproducibility and high efficiency. Energy Environ. Sci. (2016). doi:10.1039/C5EE03874J

8. S.N. Habisreutinger, T. Leijtens, G.E. Eperon, S.D. Stranks, R.J. Nicholas, H.J. Snaith, Carbon nanotube/polymer composites as a highly stable hole collection layer in perovskite solar cells. Nano Lett. 14(10), 5561-5568 (2014). doi:10.1021/n1501982b

9. L. Etgar, P. Gao, Z. Xue, Q. Peng, A.K. Chandiran, B. Liu, M.K. Nazeeruddin, M. Grätzel, Mesoscopic $\mathrm{CH}_{3} \mathrm{NH}_{3} \mathrm{PbI}_{3} / \mathrm{TiO}_{2}$ heterojunction solar cells. J. Am. Chem. Soc. 134(42), 17396-17399 (2012). doi:10.1021/ja307789s

10. W.A. Laban, L. Etgar, Hole conductor-free lead halide iodide heterojunction solar cells. Energy Environ. Sci. 6, 3249-3253 (2013). doi:10.1039/C3EE42282H

11. S. Aharon, S. Gamliel, B.E. Cohen, L. Etgar, Depletion region effect of highly efficient hole conductor free $\mathrm{CH}_{3} \mathrm{NH}_{3} \mathrm{PbI}_{3}$ perovskite solar cells. Phys. Chem. Chem. Phys. 16(22), 10512-10518 (2014). doi:10.1039/C4CP00460D

12. J.J. Shi, J. Dong, S.T. Lv, Y.Z. Xu, L.F. Zhu et al., Hole-conductor-free perovskite organic lead iodide heterojunction thinfilm solar cells: high efficiency and junction property. Appl. Phys. Lett. 104(6), 063901 (2014). doi:10.1063/1.4864638

13. D.W. Zhang, X.D. Li, H.B. Li, S. Chen, Z. Sun, X.J. Yin, S.M. Huang, Graphene-based counter electrode for dye-sensitized solar cells. Carbon 49(15), 5382-5388 (2011). doi:10.1016/j.carbon. 2011.08.005

14. P. Zhang, Z. Hu, Y. Wang, Y. Qin, W. Li, J. Wang, A bi-layer composite film based on $\mathrm{TiO}_{2}$ hollow spheres, P25, and multiwalled carbon nanotubes for efficient photoanode of dye-sensitized solar cell. Nano-Micro Lett. (2016). doi:10.1007/s40820015-0081-1

15. S. Lawes, A. Riese, Q. Sun, N. Cheng, Printing nanostructured carbon for energy storage and conversion applications. Carbon 92, 150-176 (2015). doi:10.1016/j.carbon.2015.04.008

16. Y. Zhang, L.F. Duan, Y. Zhang, J. Wang, H. Geng, Q. Zhang, Advances in conceptual electronic nanodevices based on OD and 1D nanomaterials. Nano-Micro Lett. 6(1), 1-19 (2014). doi:10. 5101/nml.v6i1.p1-19

17. A. Dualeh, N. Tétreault, T. Moehl, P. Gao, M.K. Nazeeruddin, M. Grätzel, Effect of annealing temperature on film morphology of organic-inorganic hybrid pervoskite solid-state solar cells. Adv. Funct. Mater. 24(21), 3250-3258 (2014). doi:10.1002/adfm. 201304022

18. A. Mei, X. Li, L. Liu, Z. Ku, T. Liu et al., A hole-conductor-free, fully printable mesoscopic perovskite solar cell with high stability. Science 345(6194), 295-298 (2014). doi:10.1126/science. 1254763
19. H. Zhou, Y. Shi, Q. Dong, H. Zhang, Y. Xing, K. Wang, Y. Du, T. Ma, Hole-conductor-free, metal-electrode-free $\mathrm{TiO}_{2} / \mathrm{CH}_{3-}$ $\mathrm{NH}_{3} \mathrm{PbI}_{3}$ heterojunction solar cells based on a low-temperature carbon electrode. J. Phys. Chem. Lett. 5(18), 3241-3246 (2014). doi:10.1021/jz5017069

20. F. Zhang, X. Yang, H. Wang, M. Cheng, J. Zhao, L. Sun, Structure engineering of hole-conductor free perovskite-based solar cells with low-temperature-processed commercial carbon paste as cathode. ACS Appl. Mater. Interfaces 6(18), 16140-16146 (2014). doi:10.1021/am504175x

21. V. D'Innocenzo, G. Grancini, M.J.P. Alcocer, A.R.S. Kandada, S.D. Stranks, M.M. Lee, G. Lanzani, H.J. Snaith, A. Petrozza, Excitons versus free charges in organo-lead tri-halide perovskites. Nat. Commun. 5(4), 3586 (2014). doi:10.1038/ ncomms 4586

22. H. Yu, F. Wang, F. Xie, W. Li, J. Chen, N. Zhao, The role of chlorine in the formation process of " $\mathrm{CH}_{3} \mathrm{NH}_{3} \mathrm{PbI}_{3-\mathrm{x}} \mathrm{Cl}_{\mathrm{x}}$ " perovskite. Adv. Funct. Mater. 24, 7102-7108 (2014). doi:10.1002/ adfm. 201401872

23. N.J. Jeon, J.H. Noh, W.S. Yang, Y.C. Kim, S. Ryu, J. Seo, S.I. Seok, Compositional engineering of perovskite materials for high-performance solar cells. Nature 517(7535), 476-480 (2015). doi:10.1038/nature 14133

24. Y.-J. Jeon, S. Lee, R. Kang, J.-E. Kim, J.-S. Yeo, S.-H. Lee, S.-S. Kim, J.-M. Yun, D.-Y. Kim, Planar heterojunction perovskite solar cells with superior reproducibility. Sci. Rep. 4, 6953 (2014). doi:10.1038/srep06953

25. P.W. Liang, C.Y. Liao, C.C. Chueh, F. Zuo, S.T. Williams, X.K. Xin, J.J. Lin, A.K. Jen, Additive enhanced crystallization of solution-processed perovskite for highly efficient planar-heterojunction solar cells. Adv. Mater. 26(22), 3748-3754 (2014). doi:10.1002/adma.201400231

26. N.J. Jeon, J.H. Noh, Y.C. Kim, W.S. Yang, S. Ryu, S.I. Seok, Solvent engineering for high-performance inorganic-organic hybrid perovskite solar cells. Nat. Mater. 13(9), 897-903 (2014). doi:10.1038/nmat4014

27. M. Xiao, F. Huang, W. Huang, Y. Dkhissi, Y. Zhu, J. Etheridge, A.G. Weale, U. Bach, Y.B. Cheng, L. Spiccia, A fast depositioncrystallization procedure for highly efficient lead iodide perovskite thin-film solar cells. Angew. Chem. 126(37), 10056-10061 (2014). doi:10.1002/ange.201405334

28. J. Seo, S. Park, Y.C. Kim, N.J. Jeon, J.H. Noh, S.C. Yoon, S.I. Seok, Benefits of very thin PCBM and LiF layers for solutionprocessed p-i-n perovskite solar cells. Energy Environ. Sci. 7(7), 2642-2646 (2014). doi:10.1039/c4ee01216j

29. J. Shi, Y. Luo, H. Wei, J. Luo, J. Dong et al., Modified two-step deposition method for high-efficiency $\mathrm{TiO}_{2} / \mathrm{CH}_{3} \mathrm{NH}_{3} \mathrm{PbI}_{3}$ heterojunction solar cells. ACS Appl. Mater. Interfaces 6(12), 9711-9718 (2014). doi:10.1021/am502131t

30. J.H. Im, C.R. Lee, J.W. Lee, S.W. Park, N.G. Park, 6.5\% Efficient perovskite quantum-dot-sensitized solar cell. Nanoscale 3(10), 4088-4093 (2011). doi:10.1039/c1nr10867k

31. Y.D. Luo, X.H. Chen, C.X. Zhang, J.J. Li, J.H. Shi, Z. Sun, Z.C. Wang, S.M. Huang, AgAl alloy electrode for efficient perovskite solar cells. RSC Adv. 5(69), 56037-56044 (2015). doi:10.1039/ C5RA06133D

32. Z.Y. Jiang, X.H. Chen, X.H. Lin, X.K. Jia, J.F. Wang, L.K. Pan, S.M. Huang, F. Zhu, Z. Sun, Amazing stable open-circuit voltage in perovskite solar cells using $\mathrm{AgAl}$ alloy electrode. Sol. Energy Mater. Sol. Cells 146, 35-43 (2016). doi:10.1016/j.solmat.2015.11.026

33. Y. Zhao, K. Zhu, $\mathrm{CH}_{3} \mathrm{NH}_{3} \mathrm{Cl}$-assisted one-step solution growth of $\mathrm{CH}_{3} \mathrm{NH}_{3} \mathrm{PbI}_{3}$ : structure, charge-carrier dynamics, and photovoltaic properties of perovskite solar cells. J. Phys. Chem. C 118(18), 9412-9418 (2014). doi:10.1021/jp502696w

34. G.E. Eperon, V.M. Burlakov, P. Docampo, A. Goriely, H.J. Snaith, Morphological control for high performance, solution- 
processed planar heterojunction perovskite solar cells. Adv. Funct. Mater. 24(1), 151-157 (2014). doi:10.1002/adfm. 201302090

35. J. Qiu, Y. Qiu, K. Yan, M. Zhong, C. Mu, H. Yan, S. Yang, Allsolid-state hybrid solar cells based on a new organometal halide perovskite sensitizer and one-dimensional $\mathrm{TiO}_{2}$ nanowire arrays. Nanoscale 5(8), 3245-3248 (2013). doi:10.1039/ C3NR00218G

36. T. Baikie, Y. Fang, J.M. Kadro, M. Schreyer, F. Wei, S.G. Mhaisalkar, M. Grätzel, T.J. White, Synthesis and crystal chemistry of the hybrid perovskite $\left(\mathrm{CH}_{3} \mathrm{NH}_{3}\right) \mathrm{PbI}_{3}$ for solid-state sensitized solar cell applications. J. Mater. Chem. A 1(18), 5628-5641 (2013). doi:10.1039/C3TA10518K

37. Q. Chen, H. Zhou, T.B. Song, S. Luo, Z. Hong, H.S. Duan, L. Dou, Y. Liu, Y. Yang, Controllable self-induced passivation of hybrid lead iodide perovskites toward high performance solar cells. Nano Lett. 14(7), 4158-4163 (2014). doi:10.1021/ nl501838y

38. Y. Li, J. Cooper, R. Buonsanti, C. Giannini, Y. Liu, F. Toma, I. Sharp, Fabrication of planar heterojunction perovskite solar cells by controlled low-pressure vapor annealing. J. Phys. Chem. Lett. 6(3), 493-499 (2015). doi:10.1021/jz502720a
39. M. Bashahu, A. Habyarimana, Review and test of methods for determination of the solar cell series resistance. Renew. Energy 6(2), 129-138 (1995). doi:10.1016/0960-1481(94)E0021-V

40. K. Bouzidi, M. Chegaar, A. Bouhemadou, Solar cells parameters evaluation considering the series and shunt resistance. Energy Mater. Sol. Cells 91(18), 1647-1651 (2007). doi:10.1021/acsami.5b09873

41. Y. Wu, A. Islam, X. Yang, C. Qin, J. Liu, K. Zhang, W. Peng, L. Han, Retarding the crystallization of $\mathrm{PbI}_{2}$ for highly reproducible planar-structured perovskite solar cells via sequential deposition. Energy Environ. Sci. 7(9), 2934-2938 (2014). doi:10.1039/ C4EE01624F

42. K.E. Strawhecker, S.K. Kumar, J.F. Douglas, A. Karim, The critical role of solvent evaporation on the roughness of spin-cast polymer films. Macromolecules 34(14), 4669-4672 (2001). doi:10.1021/ma001440d

43. P. Müller-Buschbaum, J.S. Gutmann, M. Wolkenhauer, J. Kraus, M. Stamm, D. Smilgies, W. Petry, Solvent-induced surface morphology of thin polymer films. Macromolecules 34(5), 1369-1375 (2001). doi:10.1021/ma0009193 